\title{
Albanon
}

Revistë kulturore

\section{Konvertimi në një fe i shqiptarëve, rezultoi i pamundur..}

Shefqet Deliallisi

Është interesant dhe i pak përmendur fakti se kthimi i shqiptarëve në një fe të vetme, është parë si mundësi, kur Peranoria Osmane po shpërbëhej.

Edhe më interesant: si fe e përbashkët ishte menduar krishtërimi protestant. A ishte ky konvertim i mundur?

Sipas mbështetësve të kësaj teze, pse jo. A nuk e kishin ndryshuar edhe më parë shqiptarët fenë? A nuk i kishin shqiptarët rrënjët e tyre në Europë? A nuk ishin shkëputur ata forcërisht prej saj?

Për më tepër, shqiptarët kishin dhënë prova se pragmatizmin e kishin më të fortë se ndjenjën fetare. Le të kujtojmë, këmbënguljen e Mbretit Zog, vite më vonë, për t’u martuar me çdo kusht me një europiane të krishterë... Pra shqiptarët e shihnin, se interesi i tyre ishte në Europën e krishterë, të pasur e të fuqishme.

Shqiptarët e dëshironin fort kthimin në Europë, por a i pranonte Europa e krishterë me fetë që ata kishin? Në Librin "Brenga e Ballkanit" Edith Durham shkruan (f. 81):

“Elbasani ka rreth 10 mijë banorë, me shumë se gjysma janë myslymanë. Të krishterët janë ortodoksë... Patriotizmi në këtë zonë është i zjarrtë dhe qëndron mbi të gjitha doktrinat fetare. Nga çpashë e dëgjova mora vesh se me t’u çliruar nga zgjedha turke fshatra të tëra, që tani e mbanin veten për myslymanë do të ktheheshin në të krishterë...."

Por problemi s'mbaronte këtu. Vërtet do të ktheheshin në të krishterë, por çfarë; të krishterë ortodoksë apo katolikë? 
Durhami vazhdon:

"Shumë të krishterë e quajnë veten katolikë, duke thënë se prapa kishës ortodokse qëndronte Rusia dhe Greqia, pra tirania; kurse prapa Romës qëndronin njerëz të mësuar në Perëndim dhe qytetërim... "

Por vështrimi ishte hedhur edhe përtej ortodoksisë dhe katolicizmit. Propozohej protestanizmi, duke menduar se do të pranohej më lehtë, mbasi ishte fe që nuk i përkiste asnjërit prej tri komuniteteve fetare.

Sot, ideja për kthimin e shqiptarëve në të krishterë protestantë mund të duket e çuditshme. Por... a s'ishte vetë Europa disa vite më vonë që përzgjodhi mes kandidatëve për mbret të shqiptarëve, si më të përshtatshmin, princ Vidin, pikërisht se ishte i krishterë protestant?

Pra, protestanizmi parapëlqehej. Askush nga komunitetet fetare s'do të ndjehej superior. Askush s'do të ndjehej i lënduar.

Sigurisht që s'ishte vetëm kjo. Protestanizmi pëlqehej edhe se ishte fe e vendeve të fuqishme dhe shumë të zhvilluara perëndimore.

Le të kthehemi prapa në kohë....Elbasan, viti 1908. Dy misionarë të Shoqërisë Biblike, njëri amerikan, Charles Teleford Erikson dhe tjetri shqiptaroamerikan, Grigor Cilka, ndodheshin në Shqipëri. Misioni final: përhapja e protestanizmit. Për të lehtësuar misionin e tyre, si hap të parë ishte menduar themelimi i shkollave shqipe; botimi dhe përhapja e librave shqipe; përhapja e Ungjillit, tashmë të përkthyer shqip nga Kristoforidhi dhe hap pas hapi kthim të shqiptarëve në të krishterë protestantë.

Është fakt i njohur se misionarët e Shoqërisë Biblike, motrat dhe vëllezërit Qiriazi, Grigor Cilka etj., u investuan fort për përhapjen e gjuhës shqipe, në Kongresin e Manastirit e më tej.

Por le të khehemi në Elbasan, në vitin 1908. Në librin e tij "ShqiptarëtEnigma e Ballkanit", misionari amerikan, mik i shqiptarëve, Erikson shkruan:

"Njeri prej burrave më të mëdhenj të Shqipërisë, Aqif Pasha i Elbasanit, një burrë i jashtzakonshëm, me karakter të patundur, me ndikim në tërë Shqipërinë, si mbi myslymanët edhe të krishterët, më thirri një ditë dhe më dha një prej mësimeve më të vështira që kam marrë ndonjëherë në jetën time:

-Unë e di që ju keni ardhur në Shqipëri për të bërë punë të mira, për t’i edukuar shqiptarët dhe aftësuar ata që të jenë më pak fanatikë dhe të urrehen më pak me njeri tjetrin. Nëse ju do tia arrini kësaj, ne mund të dalim të zgjidhim problemin më të madh që ka vendi ynë. T'u jepet shqiptarëve vetëm një fe, dhe kështu të 


\section{Albanon}

\section{Revistë kulturore}

bashkonen në një vllazëri shpirtërore. Por, për të arritur këtë ju duhet të përfitoni nga rasti $i$ kësaj mundësie të jashtëzakonshme që na është dhënë në këtë kohë qё po flasim, kur udhëheqsit tanë kudo që janë, e dinë nevojën e menjëhershme dhe janë përgatitur të punojnë dhe sakrifikojnë për të. Do të ishim të pashpresë nëse presim që cilado prej të tri feve të vjetra që gjënden këtu, ajo muhamedane, $e$ krishterë romake apo ortodokse, të përfshijë dy të tjerat dhe shqiptarët të bashkohen në një fe të vetme. Kanë ndodhur aq shumë gjëra të panevojshme, përplasje deri në gjakderdjhje midis tyre; ka patur përzierje të panevojshme të politikës nga jashtë në këto ngatrresa, me qëllim thartimin e këtyre mardhënieve midis shqipëtarve, bazuar në dallimet fetare, deri në nxitje vllavrasaëse. E gjithë kjo e ka patur si qëllim ta bënte bashkimin tonë të pamundur.

Protestanizmi mund ta mundësojë këtë, sepse ai është i lirë nga këto pengesa dhe nxit arsimimin, lirinë politike dhe fetare, drejtësinë shoqërore, të gjitha këto që neve na nevojiten kaq shumë. Por ju duhet ti bindeni maksimës amerikane; "koha është flori”... ..(f1.13)

Zëri i pashait atdhetar, që i përkiste fesë myslimane (sektit bektashi) nuk ishte i vetmuar. Siç ai vetë thekson: "udhëheqsit tanë kudo që janë, e dinë nevojën e menjëhershme dhe janë përgatitur të punojnë dhe sakrifkojnë për të (konvertimin). Një prej tyre ishte edhe Lef Nosi një tjetër atdhetar i shquar. Ja ç'shkruan Eriksoni në librin e tij :

"Lef Nosi, pjesëtar i kishës Ortodokse Greke gjithashtu më pat thënë : 'Ne e dimë që ju e keni ilaçin e duhur shërues, që po t’i jepet popullit tonë, do t’ia shpëtojë jetën. Por çfarë po bëni ju për këtë? Ju vetëm sa na e tregoni atë. Kur ju kërkojmë ta hapni dhe të na e jepni ta pimë, ju thoni prisni pak, se ende nuk jeni gati. Ne po vdesim... Nëse vërtet na doni të na ruani, hapeni barin shërues të sëmundjes dhe na shëroni. Nëse nuk e bëni këtë, ju lutem, na lini të provojmë diçka tjetër ose na lini të vdesim në paqe”.(f1.14)

Megjithatë, projekti për kthimin e shqiptarëve në një fe të vetme, të krishterë protestantë, nuk eci. Duket ideja ishte utopike. Duket shqiptarët ishin të papërgatitur. Shtetet fqinje, me pretendimet e tyre ndaj Shqipërisë ishin një pengesë serioze. Atyre i interesonte të ruhej status quo fetare në mënyrë që përçarja mes shqiptarëve të pengonte bashkimin në një shtet.

Ja si e përshkruan situatën në Shqipëri gazetari amerikan i "The Chicago Daily News” Paul Scott Mowrer, në shkrimin e tij "Shënime udhëtimi” publikuar në Gazetën Ilustracion në 29 Mars 1913. Ishte koha kur serbët kishin dalë në detin Adriatik, pasi kishin pushtuar një pjesë të Shqipërisë : 
"Feja në Ballkan shihet nga dy këndvështrime : në aspektin shpirtëror dhe atë politik. Nga ana shpirtërore dua të besoj se krerët e të gjitha besimeve dhe sekteve aspironin shpëtimin e shpirtrave, por nga ana politike, këta njerëz tregoheshin mjaft xhelozë për njeri-tjetrin. Shqiptarët myslimanë, si të painteresuar për këtë çeshtje, na siguruan se peshkopi ortodoks grek i Durrësit, kishte kohë që nxiste urrejtje kundër Eriksonit dhe Cilkës. Ky peshkop do të kish dashur në fakt qü kristianizimi, në rast se duhej të përhapej në Shqipëri, të përhapej nën mbrojtjen e mbikqyrjen e tij. Meqenëse feja ortodokse greke ishte dhe fe e shtetit serb, qeveria e Beogradit e cila ishte mjaft e lidhur me besimin fetar, ndaloi rreptësisht krijimin dhe ushtrimin e një besimi tjetër. Sapo Peshkopi i Durrësit mësoi se serbët hynë në Elbasan, u nis për atje dhe të nesërmen Cilka u arrestua..."

Vite më vonë këtë orvatje e përmend një tjetër atdhetar mendjehapur, Hamid Gjylbegaj, në libërthin “Kopje Origjinale” botuar në Shkodër, në vitin 1931, në shkrimin me titull "Verejtje historike” ai shkruan:

"Asht nji e vërtetë e pa-mohueshme se, veprat kryesore të ndijertit Zotni Kristoforidhit, ... e vertetojnë faktin historik se Kisha Orthodhokse e ka pasë humbun gjuhen amtare të veden, e ka kenë bam kamb-e-krye, Ruso-Grekobizahtine. Shi për ket arsye, dashamirja e Kombit tonë, Anglia, tuj e parapa rrezikun qi na kercnohej, asht mundue çme kohë me e shkoqë Kishen Orthodhokse të Shqipnis prej duerve të forta të Panslavizmit, e madje prandej Zotnis të naltpërmendun $i$ ka pasë pague nji rrogë, sidomos për ato kohë, mjaftë të majme për e përkthye Unjillin e me bamun fjalorin shqip, origjinali i të cillit, mjerisht, ende sot gjindet i shitun n'Athinë!...Pra, kish tishte pas përhapun gjuha amtare çme kohë, e bashkë me kte edhe propaganda e fillueme e Protistanizmit, ndoshta do t'iu ishte pas mrritun qellimit në skaj të vet; por, për deri tash, çka u pa me sye e u ndi me veshë, puna na diftoj të kunderten..."

Por le t'i kthehemi lidhjes së Kostandin Kristoforidhit me protestantët; pyetjes së vjetër: A ishte konvertuar Kristoforidhi në fenë protestante?

Dihet që Kristoforidhi ka punuar me Shoqërinë Biblike Britanike për përkthimin e teksteve biblike në gjuhën shqipe. Dihet simpatia e tij për Protestanizmin. Këtë e gjejmë edhe në "Anekdoda" të mbledhura nga Lef Nosi (dorëshkrim origjinal) në një prej të cilave flet për mendimin e Kristoforidhi mbi fetë:

“...kur e pytën (Kristoforidhin) për protestanët, katolikët e ortodoksët ai tha: "ortodoksët e katolikët janë një thes me kashtë, me nga nji koqe gruni mbrenda. Protestantët qitën kashtën e mbeti gruni...” (Spiro Xhufka) AQSH, fondi Lef Nosi, dosja 49, f. 1 


\section{Albanon}

\section{Revistë kulturore}

Por a ishte konvertuar ai në fenë protestante?

Kohët e fundit, Dr. David Hosaflook, në një konferencë ndërballkanike, me rastin e $\mathbf{5 0 0}$ vjetorit të protestanizmit, në shkrimin : "Kush ishte i pari protestant shqiptar?", pretendon zbulimin e një dokumenti, sipas të cilit në vitin 1857 Kostandin Kristoforidhi është konvertuar në besimin protestant. "Njoftimin, - shkruan ai, - e kemi nga misionarët amerikanë Daniel Ladd dhe Edward Dodd, të cilët punonin në kishën protestante në Smirnë, ku ndodhej edhe Kristoforidhi. Në raportin vjetor të Shoqërisë në Ndihmë të Misioneve në Turqi, për vitin 1856-1857, zbulojmë se Kristoforidhi u anëtarësua në një kishë protestante disa vite para se të lidhej me Aleksandër Tomsonin, Shoqërinë Biblike." (Gazeta Shqiptare, 19 nëntor 2017 "Kush ishte i pari protestant shqiptar?” Dr. David Hosaflook). Gjithsesi kjo mbetet per t'u hulumtuar me tej.

Duke iu kthyer fillimit të shkrimit, shqiptarët nuk u kthyen dot në një fe të vetme. Duket kjo ishte e pamundur. Ashtu siç i pamundur rezultoi dhe "konvertimi" me dhunë në një "pafe" të vetme, ateizmin, që diktatura komuniste tentoi ta bënte gjithashtu. Sapo diktatura ra, shqiptarët u rikthyen te tri fetë e mëparshme...

Gjithsesi shqiptarët ia arritën të krijojnë shtetin shqiptar, ndonëse mjaft të cunguar. Pengesën e tri feve të ndryshme, ata e tejkaluan nëpërmjet gjuhës së përbashkët dhe... tolerancës fetare. Kombi shqiptar mbijetoi dhe duke u forcuar, hap pas hapi, po shkon drejt bashkimit, në Europën e bashkuar.... 